\title{
Evaluation of compounds for repellency of the multicoloured Asian lady beetle (Coleoptera: Coccinellidae) in vineyards
}

\author{
Erik Glemser $^{1 \star}\left(\mathbb{D}\right.$, Wendy McFadden-Smith ${ }^{2}$, and Jean-Philippe Parent ${ }^{3}$ \\ ${ }^{1}$ Department of Plant Agriculture, University of Guelph, 50 Stone Road East, Guelph, Ontario, N1G 2W1, Canada, ${ }^{2}$ Ontario \\ Ministry of Agriculture, Food and Rural Affairs, 4890 Victoria Avenue North, Vineland Station, Ontario, L0R 2E0, Canada, \\ and ${ }^{3}$ Agriculture and Agri-Food Canada, 430 boulevard Gouin, Saint-Jean-sur-Richelieu, Québec, J3B 3E6, Canada \\ ${ }^{\star}$ Corresponding author. Email: glemsere@uoguelph.ca
}

(Received 22 July 2020; accepted 10 September 2020; first published online 02 February 2021)

\begin{abstract}
The multicoloured Asian lady beetle, Harmonia axyridis (Pallas) (Coleoptera: Coccinellidae), has become a pest in North American vineyards during harvest due to its adverse effects on wine quality. This study evaluated alternative products that may be suitable for use in vineyards as repellents to the beetle. Products were screened as repellent for multicoloured Asian lady beetle in short-term laboratory trials. Thirteen products significantly reduced the number of beetles on grapes, Vitis vinifera (Vitaceae). Products that showed a 50\% or greater repellency were evaluated for residual repellency 24 , 48 , and 72 hours after application. In these trials, pine oil was highly repellent at each testing period, whereas the repellency of most other products decreased over time. Eight repellent compounds were evaluated in field trials in commercial vineyards that had high multicoloured Asian lady beetle populations. The number of beetles on vines was counted 2-6 and 24-28 hours after application. In the field, the most effective repellents overall were Biobenton and Buran, which reduced the number of multicoloured Asian lady beetles by 39 and 34\%, respectively. The discovery of new repellents of multicoloured Asian lady beetle provides an opportunity to improve management of the pest in vineyards and to reduce risk of wine taint without using broad-spectrum insecticides.
\end{abstract}

\section{Introduction}

Harmonia axyridis (Pallas) (Coleoptera: Coccinellidae), commonly called the multicoloured Asian lady beetle, is a generalist predator native to Asia (Essig 1965). The multicoloured Asian lady beetle was introduced to North America in 1916 as a biological control agent (Gordon 1985), and it has since become the dominant coccinellid in most habitats in the United States of America and in Ontario, Canada. Its establishment had unintended consequences, as the beetle has become a nuisance in urban environments and a serious pest of wine and juice grapes (Ker and Pickering 2005).

In autumn, the beetle undertakes long-distance dispersal flights from feeding habitats to overwintering sites (Hodek et al. 1993) in response to temperature changes (Nalepa et al. 2005). It enters vineyards in the autumn and feeds on previously damaged grapes (Koch 2003), but direct yield loss from their feeding is negligible. Instead, economic loss occurs when the beetles are harvested with grapes and release defensive compounds, which can compromise the quality of wine

Subject editor: Christopher Cutler

(C) The authors and Her Majesty the Queen in Right of Canada, 2021. Published by Cambridge University Press on behalf of the Entomological Society of Canada. This is an Open Access article, distributed under the terms of the Creative Commons Attribution licence (http:// creativecommons.org/licenses/by/4.0/), which permits unrestricted re-use, distribution, and reproduction in any medium, provided the original work is properly cited. 
(Pickering et al. 2005). The aroma and taste of wine produced from grapes contaminated with multicoloured Asian lady beetle are characterised by atypical sensory attributes and a reduction in varietal attributes (Pickering et al. 2004). Sensory thresholds for the beetle in wine vary because they are influenced by many factors, including wine style, differences in wine processing techniques, and individual (i.e., consumer) sensitivities (Pickering et al. 2005; Galvan et al. 2008a). The tolerance for the beetle in harvested bins is up to the discretion of the individual winery. Many wineries around Niagara, Ontario, Canada employ a low-tolerance approach, based primarily on the number of the beetles observed on the surface of harvested bins during their precrush inspection (R. Brewster, personal communication). This is a problem for grape growers, because wineries may reject their grapes if a single lady beetle is found. To address this concern, Pickering et al. (2007) recommended that the wine industry adopt a "safe" limit of 200-400 multicoloured Asian lady beetles per tonne of grapes ( $0.75-1.5$ beetles per vine) to protect against wine taint.

Although migration of the beetle into vineyards can occur en masse (Glemser et al. 2012), populations in vineyards vary from year to year (Bahlai and Sears 2009). The most common method for controlling the beetle is the use of broad-spectrum insecticides before harvest, but these products represent a potential threat to nontarget organisms and to human health. In Canada and the United States of America, current regulations emphasise the replacement of broad-spectrum pesticides with reduced-risk products (United States Government Publishing Office 1996; Health Canada 2002). Many studies have investigated the potential of natural repellent compounds as alternatives for insect pest control (Riddick et al. 2000; Nerio et al. 2010). Repellent compounds are those that elicit avoidance behaviour in an organism (Dethier et al. 1960). Essential oils have been used as insect repellents because they are generally nontoxic to mammals (Cook et al. 2007), and many natural compounds generally are comparatively less persistent under field conditions (Ujváry 2010).

Repellent compounds may be an effective management method for this species because of their natural dispersal. Adult multicoloured Asian lady beetles are good at flying, and they can rapidly disperse from field and greenhouse crops, especially in the absence of food (Hodek et al. 1993; Tourniaire et al. 1999; Seko et al. 2008). Feeding on grapes alleviates the beetles' nutritional stress as they prepare for overwintering (Berkvens et al. 2008; Galvan et al. 2008b), and for this reason, they likely remain in vineyards; however, if the beetles encounter a repellent compound in vineyards, we believe they could be driven to disperse.

In this study, we performed laboratory and field trials to test compounds for repellency of the multicoloured Asian lady beetle. The compounds we tested are either already registered for use on grapes for another purpose or they are known repellents of other insects (Isman 2000). Additionally, many of the products would likely be considered reduced-risk pesticides (United States Government Publishing Office 1996; Health Canada 2002). This research was done to improve the management of multicoloured Asian lady beetle in vineyards by providing growers with an alternative to broad-spectrum insecticides.

\section{Material and methods}

\section{Laboratory trials}

Test compounds. Fifteen compounds with potential repellent activity were tested in laboratory trials (Table 1). Products are referenced by their formulated name when available; otherwise, they are referenced by the active ingredient(s) (Table 1). Products were initially tested for short-term residual repellency, approximately 0 hours after application. Products that showed a repellency of at least $50 \%$ were further evaluated for residual repellency at 24,48 , and 72 hours after application. Labelled products were tested at the highest label rate (Table 2). Rates of unlabelled products were determined based on reports in the literature (Bekele et al. 1996; Bin et al. 2016; Maier and Williamson 2016; Park et al. 2017; Werle et al. 2017; Bendre et al. 2018) and through preliminary 
Table 1. Products evaluated for their effect on multicoloured Asian lady beetles in short-term laboratory trials.

\begin{tabular}{|c|c|c|}
\hline $\begin{array}{l}\text { Formulated-product } \\
\text { name (if available) }\end{array}$ & Active ingredient (\%) & Supplier/Manufacturer \\
\hline Surround ${ }^{\circledR}$ WP & Kaolin clay $(5 \%)$ & $\begin{array}{l}\text { Tessenderlo Kerley, Phoenix, } \\
\text { Arizona, United States of } \\
\text { America }\end{array}$ \\
\hline Timorex Gold ${ }^{\circledR}$ & Tea tree oil (23.8\%) (Melaleuca alternifolia (Myrtaceae)) & $\begin{array}{l}\text { Stockton (Israel) Ltd., Petah } \\
\text { Tikva, Israel }\end{array}$ \\
\hline \multirow[t]{2}{*}{ Buran $^{\circledR}$} & Garlic powder (15\%) (Allium sativum (Amaryllidaceae)) & $\begin{array}{l}\text { AEF GLOBAL Inc., Lévis, Québec, } \\
\text { Canada }\end{array}$ \\
\hline & Potassium metabisulfite (100\%) & Laffort, Bordeaux Cedex, France \\
\hline Biobenton ${ }^{\circledR}$ & Bentonite $(100 \%)$ & $\begin{array}{l}\text { AO Wilson Ltd, Erin, Ontario, } \\
\text { Canada }\end{array}$ \\
\hline \multirow[t]{2}{*}{ Solfobenton ${ }^{\circledR}$} & Potassium metabisulfite $(30 \%)+$ bentonite $(70 \%)$ & $\begin{array}{l}\text { AO Wilson Ltd, Erin, Ontario, } \\
\text { Canada }\end{array}$ \\
\hline & Pine oil (80\%) (Pinus sp. (Pinaceae)) & $\begin{array}{l}\text { AEF Global, Lévis, Québec, } \\
\text { Canada }\end{array}$ \\
\hline \multirow[t]{3}{*}{ Ecotrol $^{\circledR}$ EC } & $\begin{array}{l}\text { Rosemary oil }(10 \%)(\text { Salvia rosmarinus (Lamiaceae) })+ \\
\quad \text { peppermint oil }(2 \%)(\text { Mentha } \times \text { piperita (Lamiaceae)) }\end{array}$ & $\begin{array}{l}\text { KeyPlex, Winter Park, Florida, } \\
\text { United States of America }\end{array}$ \\
\hline & Carvacrol ( $90 \%$; food grade) & $\begin{array}{l}\text { Sigma-Aldrich, Oakville, Ontario, } \\
\text { Canada }\end{array}$ \\
\hline & Basil oil (100\%; food grade) (Ocimum sp. (Lamiaceae)) & $\begin{array}{l}\text { Sigma-Aldrich, Oakville, Ontario, } \\
\text { Canada }\end{array}$ \\
\hline Fossil Shell Flower ${ }^{\circledR}$ & Diatomaceous earth (amorphous silica) & $\begin{array}{l}\text { Perma-Guard, Bountiful, Utah, } \\
\text { United States of America }\end{array}$ \\
\hline Captiva Prime $^{\circledR}$ & $\begin{array}{l}\text { Capsicum oleoresin extract (7.6\%) (Solanaceae) + garlic } \\
\text { oil }(23.4 \%)+\text { canola oil }(55.0 \%) \text { (Brassica napus } \\
\text { (Brassicaceae)) }\end{array}$ & $\begin{array}{l}\text { Gowan Company, Yuma, Arizona, } \\
\text { United States of America }\end{array}$ \\
\hline \multirow[t]{2}{*}{ Proud $3^{\circledR}$} & Thyme oil (5.6\%) (Thymus sp. (Lamiaceae)) & $\begin{array}{l}\text { Huma Gro, Gilbert, Arizona, } \\
\text { United States of America }\end{array}$ \\
\hline & Granite dust & $\begin{array}{l}\text { Heritage Memorials Ltd., } \\
\text { Windsor, Nova Scotia, Canada }\end{array}$ \\
\hline Agral ${ }^{\circledR} 90$ & Nonylphenoxy polyethoxy ethanol & $\begin{array}{l}\text { Syngenta Canada Inc., Guelph, } \\
\text { Ontario, Canada }\end{array}$ \\
\hline
\end{tabular}

laboratory trials (unreported; Table 2). Timorex Gold, potassium metabisulfite, and Fossil Shell Flower were tested at multiple rates in short-term trials to help determine potential use as a commercial repellent. The insecticide Mako (Belchim Crop Protection, Guelph, Ontario, Canada), which uses the active ingredient cypermethrin, was included as a positive control because it is registered for use on multicoloured Asian lady beetles in Ontario vineyards. Control grapes were treated with water.

Experimental design. Laboratory trials were conducted from 2017 to 2019. Multicoloured Asian lady beetles were collected from southern Ontario from August to October in each testing year, such that a permanent rearing colony was not established. A voucher specimen was deposited at the University of Guelph Insect Collection, accession number debu01089389. Studies have shown that the behavioural response of the ladybeetle Stethorus punctum picipes (Casey) (Coleoptera: 
Table 2. Mean ( \pm standard error) per cent reduction in the number of multicoloured Asian lady beetles on grape clusters treated with repellent compounds compared to clusters treated with water only. In short-term trials (STT), beetles were exposed to grapes after treatment (0-2 hours postapplication). In long-term trials (LTT), beetles were exposed to grapes 1 day (24-26 hours postapplication), 2 days (48-50 hours postapplication), or 3 days (72-74 hours postapplication) after treatment application. Treatments that were significantly different from the control are indicated by an asterisk $\left(^{*}\right)$ $(\alpha=0.05)$. When more than one rate was tested per product, rates are specified; otherwise, see Table 1 for the rates tested.

\begin{tabular}{|c|c|c|c|c|}
\hline \multirow[b]{2}{*}{ Product (rate) } & \multicolumn{4}{|c|}{ Mean ( \pm standard error) percent reduction compared to control } \\
\hline & $0-2$ hours (STT) & 24-26 hours (LTT) & 48-50 hours (LTT) & 72-74 hours (LTT) \\
\hline Surround ${ }^{\circledR}$ WP $(50 \mathrm{~g} / \mathrm{L})$ & $7( \pm 2.0)$ & - & - & - \\
\hline Timorex Gold ${ }^{\circledR}(3.3 \mathrm{~mL} / \mathrm{L})$ & $68( \pm 1.9)^{*}$ & - & - & - \\
\hline Timorex Gold ${ }^{\circledR}(15 \mathrm{~mL} / \mathrm{L})$ & $90( \pm 0.9)^{*}$ & $70( \pm 1.5)^{*}$ & $58( \pm 1.4)^{*}$ & $56( \pm 1.3)^{\star}$ \\
\hline Timorex Gold ${ }^{\circledR}(25 \mathrm{~mL} / \mathrm{L})$ & $92( \pm 0.9)^{*}$ & - & - & - \\
\hline Buran $^{\circledR}(72 \mathrm{~mL} / \mathrm{L})$ & $48( \pm 1.0)^{*}$ & - & - & - \\
\hline Solfobenton ${ }^{\circledR}(31.3 \mathrm{~g} / \mathrm{L}+1 \mathrm{~mL}$ Agral 90) & $41( \pm 1.6)^{\star}$ & - & - & - \\
\hline Biobenton ${ }^{\circledR}(31.3 \mathrm{~g} / \mathrm{L}+1 \mathrm{~mL}$ Agral 90$)$ & $38( \pm 1.6)^{*}$ & - & - & - \\
\hline Pine oil $(1 \mathrm{~mL} / \mathrm{L})$ & $81( \pm 1.0)^{\star}$ & $97( \pm 0.8)^{*}$ & $96( \pm 0.8)^{\star}$ & $97( \pm 0.5)^{\star}$ \\
\hline Ecotrol $^{\circledR} \mathrm{EC}(5 \mathrm{~mL} / \mathrm{L})$ & $60( \pm 1.2)^{*}$ & $20( \pm 1.5)^{*}$ & 0 & - \\
\hline Potassium metabisulfite $(5 \mathrm{~g} / \mathrm{L})$ & $6( \pm 1.9)$ & - & - & - \\
\hline Potassium metabisulfite $(10 \mathrm{~g} / \mathrm{L})$ & $62( \pm 1.8)^{*}$ & $38( \pm 1.7)^{*}$ & $15( \pm 1.2)^{\star}$ & $4( \pm 1.6)$ \\
\hline Carvacrol $(0.47 \mathrm{~mL} / \mathrm{L})$ & $91( \pm 0.8)^{*}$ & $32( \pm 2.0)^{\star}$ & $48( \pm 0.9)^{\star}$ & $32( \pm 1.3)^{\star}$ \\
\hline Basil oil $(0.47 \mathrm{~mL} / \mathrm{L})$ & $68( \pm 0.9)^{\star}$ & $31( \pm 1.3)^{\star}$ & $21( \pm 1.2)^{\star}$ & $7( \pm 1.3)$ \\
\hline Fossil Shell Flower ${ }^{\circledR}(5 \mathrm{~g} / \mathrm{L})$ & $15( \pm 1.5)$ & - & - & - \\
\hline Fossil Shell Flower ${ }^{\circledR}(10 \mathrm{~g} / \mathrm{L})$ & $28( \pm 1.4)^{*}$ & - & - & - \\
\hline Captiva Prime ${ }^{\circledR}(3.9 \mathrm{~mL} / \mathrm{L})$ & $28( \pm 0.9)^{\star}$ & - & - & - \\
\hline Proud $3^{\circledR}(8.3 \mathrm{~mL} / \mathrm{L})$ & $41( \pm 1.4)^{*}$ & - & - & - \\
\hline Granite dust ( $250 \mathrm{~g} / \mathrm{L}+1 \mathrm{~mL}$ Agral 90) & $86( \pm 1.6)^{\star}$ & $62( \pm 1.5)^{\star}$ & $39( \pm 1.7)^{\star}$ & $25( \pm 1.5)^{\star}$ \\
\hline Agral $^{\circledR} 90(1 \mathrm{~mL} / \mathrm{L})$ & 0 & - & - & - \\
\hline
\end{tabular}

Coccinellidae) to plant volatiles is affected by seasonal changes (James and Price 2004; James 2005). For this reason, multicoloured Asian lady beetles were maintained in mesh cages outdoors so that their physiological state and behavioural response to test compounds would be the same as their counterparts in vineyards. The lab-maintained beetles were fed a mixture of aphids. Twentyfour hours before the start of an experiment, arbitrarily selected adult beetles were removed from the mesh cages and placed in holding containers, without food, in groups of 15.

Short-term repellency trial. The repellency of each compound was evaluated using a two-choice experiment with treated and untreated grapes (variety: Cabernet franc), similar to methods previously used to evaluate multicoloured Asian lady beetle and repellents (Riddick et al. 2000, 2008). Grapes were collected from a commercial vineyard in Niagara, Ontario and washed with soap and water to remove potential pesticides. Grapes from the same cluster, with berries left on the rachis, were used in each experimental container $\left(36 \mathrm{~cm} \mathrm{~L} \times 24 \mathrm{~cm} \mathrm{~W} \times 8 \mathrm{~cm} \mathrm{H}\right.$; Ziplock ${ }^{\circledR}$, SC Johnson \& Son, Inc., Racine, Wisconsin, United States of America). Treatment and control clusters were of similar ripeness (based on colour) and size (based on number of berries). Because multicoloured Asian lady beetles are unable to feed on intact grapes, the grapes were damaged by cutting 5-8 $\mathrm{mm}$ incisions in the skins using scissors. Each cluster was dipped into the corresponding treatment 
solution, dried on a rack for five minutes, and then placed in experimental containers, as described above. Each container received a control cluster and a treated cluster placed at opposite ends of the container and separated by approximately $15 \mathrm{~cm}$. A ventilated lid was placed on each container to prevent the accumulation of volatile compounds. A group of 15 multicoloured Asian lady beetles was released in each experimental container, at which point the observation period started. The number of beetles on each cluster was counted at 5, 10, 20,30,40,50,60, 90, and 120 minutes. Beetles were considered to be on the grapes if any part of their body was touching a grape or rachis. Each treatment was replicated 9-10 times.

Long-term repellency trial. Products that showed a repellency of at least 50\% in short-term repellency trials were further evaluated for repellency at 24,48 , and 72 hours after application. The methods used were similar to the short-term trials, but store-bought table grapes were used instead of commercial vineyard grapes. Dried, product-treated grapes were placed in experimental containers for 72 hours. Multicoloured Asian lady beetles were added to experimental containers 24 hours after treatment application, and the number of beetles on each cluster was recorded at 10,20, 30, 40, 50, $60,70,80,90,100$, and 110 minutes. After this observation period, the beetles were removed from the experimental containers and returned to the holding containers. This process was repeated at 48 and 72 hours after treatment application using new beetles. Each treatment was replicated 10 times.

\section{Field trials}

Test compounds. The following treatments were evaluated: Biobenton ${ }^{\circledR}(31.3 \mathrm{~g} / \mathrm{L})$, Solfobenton ${ }^{\circledR}$ (31.3 g/L), pine oil (1 mL/L), Ecotrol ${ }^{\circledR}$ EC $(5 \mathrm{~mL} / \mathrm{L}), \operatorname{Buran}^{\circledR}(72 \mathrm{~mL} / \mathrm{L})$, Timorex Gold $^{\circledR}(3.3 \mathrm{~mL} / \mathrm{L})$, potassium metabisulfite $(10 \mathrm{~g} / \mathrm{L})$, Agral $^{\circledast} 90(1 \mathrm{~mL} / \mathrm{L})$, Mako ${ }^{\circledR}(0.25 \mathrm{~mL} / \mathrm{L}$ and $600 \mathrm{~L} / \mathrm{ha}$; Belchim Crop Protection Canada Inc. 2019), and a water control (see Table 1 for a complete list of products tested, active ingredients, and manufacturers or suppliers). Full-canopy treatments were applied at $800 \mathrm{~L} / \mathrm{ha}$ (excluding Mako) using a calibrated $\mathrm{CO}_{2}$ backpack sprayer at 40 psi.

Experimental design. Field trials were conducted in two commercial vineyards with high multicoloured Asian lady beetle populations in 2017: a Riesling block in the Beamsville Bench designated viticultural area (Beamsville, Ontario, Canada) and a Pinot noir block in the Creek Shores designated viticultural area (St. Catharines, Ontario, Canada; see http://www.vqaontario.ca/ Appellations [accessed 8 November 2020]). Row and vine spacing were $2.4 \mathrm{~m} \times 1 \mathrm{~m}$ in the Riesling block and $2.3 \mathrm{~m} \times 1.2 \mathrm{~m}$ in the Pinot noir block. Each plot consisted of a panel of five vines. Treatments were replicated five times in a randomised complete block design.

Treatments were applied in the morning once the canopy had dried. The Riesling and Pinot noir blocks were sprayed on 24 and 26 October 2017, respectively. Treatment panels were at least one panel away from the edge of the row to avoid potential edge effects. Additionally, treatment panels were always separated by an untreated panel within the same row.

The number of multicoloured Asian lady beetles on vines (fruiting zone and canopy) was counted at 2-6 hours (Day 0) and 24-28 hours (Day 1) after spraying. Counts were performed on five vines per panel. Counting was done by two technicians examining the same vine, one on either side of the row. This counting technique increased accuracy by limiting the potential for double counting or overlooking beetles. Vines were examined carefully to avoid disturbing the beetles.

Temperature, humidity, and precipitation in the block were recorded every hour using an ONSET HOBO remote monitoring system (Hoskins Scientific, Burlington, Ontario, Canada). The daily mean wind speed $(\mathrm{km} / \mathrm{h})$ at $10 \mathrm{~m}$ off the ground was obtained from Weather Innovations Consulting LP (Riesling: Beamsville station; Pinot noir: St. Catharines Third Avenue station, https://www.weatherinnovations.com [accessed 13 December 2017]; Chatham, 
Ontario, Canada). It was our intention to continue to evaluate these products in further field trials, but this did not occur due to low beetle populations in 2018 and 2019.

\section{Statistical analyses}

Laboratory trials. Statistical analyses were performed using SAS 9.4 (SAS Institute, Cary, North Carolina, United States of America) using a type I error rate $(\alpha)$ of 0.05 . The numbers of multicoloured Asian lady beetles on control and treated clusters were expressed as a proportion of the total number in each container. Data were subjected to an analysis of variance using SAS's PROC GLIMMIX, with time intervals as a repeated measure. Analysis of residuals was performed to test the validity of model assumptions. Treatment means were separated using Tukey's multiple comparisons test.

Field trials. The number of multicoloured Asian lady beetles per panel was subjected to an analysis of variance using PROC GLIMMIX. Analyses were performed on both locations and days, with the latter as a repeated measure. The fixed effects of treatment, location, day, and their interactions were examined. Blocks were designated a random effect nested within location. Least-square means were used to determine treatment effects for individual days and overall. Ecotrol EC and Solfobenton were replicated four times in the Riesling and Pinot noir trials, respectively, due to problems that occurred during spraying. These replicates were considered missing-response values during analysis. No significant interactions involved the effect of treatment with either location or day; therefore, the effect of treatments was compared directly. Analysis of residuals was performed to test the validity of model assumptions.

\section{Results}

\section{Laboratory trials}

Results from the laboratory trials are shown in Table 2. In the short-term trials, multicoloured Asian lady beetles were significantly repelled by Timorex Gold at each rate $\left(3.3 \mathrm{~mL} / \mathrm{L}: F_{1,8}=48.5\right.$, $\left.P<0.001 ; 15 \mathrm{~mL} / \mathrm{L}: F_{1,9}=303.7, P<0.001 ; 25 \mathrm{~mL} / \mathrm{L}: F_{1,8}=55.0, P<0.001\right)$, Buran $\left(F_{1,8}=16.0\right.$, $P<0.001)$, Solfobenton $\left(F_{1,9}=74.7, P<0.001\right)$, Biobenton $\left(F_{1,8}=20.1, P=0.002\right)$, pine oil $\left(F_{1,8}=75.5, P<0.001\right)$, Ecotrol EC $\left(F_{1,8}=20.5, P=0.002\right)$, potassium metabisulfite $10 \mathrm{~g} / \mathrm{L}$ $\left(F_{1,9}=50.4, P<0.001\right)$, carvacrol $\left(F_{1,9}=108.4, P<0.001\right)$, basil oil $\left(F_{1,9}=96.1, P<0.001\right)$, Fossil Shell Flower $10 \mathrm{~g} / \mathrm{L}\left(F_{1,9}=10.7, P=0.010\right)$, Captiva Prime $\left(F_{1,9}=7.6, P=0.022\right)$, Proud $3\left(F_{1,9}=35.9, P<0.001\right)$, and granite dust $\left(F_{1,9}=199.4, P<0.001\right)$, whereas no repellent effects occurred with Surround WP $\left(F_{1,8}=0.52, P=0.493\right)$, potassium metabisulfite $5 \mathrm{~g} / \mathrm{L}\left(F_{1,9}=0.24\right.$, $P=0.636)$, Fossil Shell Flower $5 \mathrm{~g} / \mathrm{L}\left(F_{1,9}=2.4, P=0.156\right)$, and Agral $90\left(F_{1,8}=1.6, P=0.236\right)$.

In long-term trials, multicoloured Asian lady beetles were significantly repelled at every time point using Timorex Gold $15 \mathrm{~mL} / \mathrm{L}$ (24 hours: $F_{1,9}=173.8, P<0.001$; 48 hours: $F_{1,9}=266.5$, $P<0.001 ; 72$ hours: $F_{1,9}=175.2, P<0.001$ ), pine oil (24 hours: $F_{1,9}=93.4, P<0.001$; 48 hours: $F_{1,9}=133.0, P<0.001 ; 72$ hours: $F_{1,9}=151.8, P<0.001$ ), carvacrol $\left(24\right.$ hours: $F_{1,9}=32.9$, $P<0.001$; 48 hours: $F_{1,9}=103.0, P<0.001 ; 72$ hours: $F_{1,9}=34.0, P<0.001$ ), and granite dust (24 hours: $F_{1,9}=185.8, \quad P<0.001 ; 48$ hours: $F_{1,9}=97.5, \quad P<0.001 ; 72$ hours: $F_{1,9}=28.0$, $P<0.001)$. Potassium metabisulfite $10 \mathrm{~g} / \mathrm{L}$ was repellent at 24 hours $\left(F_{1,9}=55.5, P<0.001\right)$ and 48 hours $\left(F_{1,9}=9.2, P<0.0141\right)$ but not at 72 hours $\left(F_{1,9}=0.6, P=0.479\right)$. Similarly, basil oil was repellent at 24 hours $\left(F_{1,9}=77.9, P<0.001\right)$ and 48 hours $\left(F_{1,9}=25.3, P<0.001\right)$ but not at 72 hours $\left(F_{1,9}=1.9, P=0.197\right)$. Ecotrol $\mathrm{EC}$ was repellent at 24 hours $\left(F_{1,9}=10.5, P=0.010\right)$ but not at 48 hours $\left(F_{1,9}=0.2, P=0.664\right)$, so 72 hours was not tested. Residual analysis showed that model assumptions were met. 


\section{Field trials}

The number of beetles found on panels was significantly influenced by treatment $\left(F_{10,174}=3.4\right.$, $P<0.001)$ and day $\left(F_{1,174}=6.3, P=0.013\right)$, but location was not significant $\left(F_{1,8}=0.9, P=0.364\right)$. Interactions involving treatment were not significant (location $\times$ treatment: $F_{10,174}=0.8, P=0.588$; day $\times$ treatment: $F_{10,174}=0.4, P=0.927$ ); however, the location $\times$ day interaction was significant $\left(F_{1,174}=33.3, P<0.001\right)$.

Panels treated with Mako had significantly fewer beetles on Day 0 (Table 3) compared to the control. Panels treated with Biobenton, Solfobenton, and Mako had significantly fewer beetles on Day 1 (Table 3) compared to the control. When counting periods were combined and analysed, panels treated with Biobenton, Buran, and Mako had significantly fewer beetles compared to the control (Table 3).

The relative reduction of numbers of beetles was more often higher on Day 1 compared to Day 0 (Table 3). Likewise, no treatments were significantly repellent on Day 0 (excluding Mako), whereas Biobenton and Solfobenton were both repellent on Day 1. Residual analysis showed that model assumptions were met.

\section{Discussion and conclusion}

The majority of products (13 of 15) tested in short-term repellency trials reduced the number of multicoloured Asian lady beetles on grapes. Some of the products evaluated in our study are known repellents, but of these products, only potassium metabisulfite had previously been tested on this species (Glemser et al. 2012). Carvacrol, Timorex Gold (highest rates), pine oil, and granite dust were highly effective and reduced the number of the beetles on grapes by more than $80 \%$. The same granite dust was repellent to cabbage looper (Trichoplusia ni) (Lepidoptera: Noctuidae), diamondback moth (Plutella xylostella) (Lepidoptera: Plutellidae), and two-spotted spider mite (Tetranychus urticae Koch) (Trombidiformes: Tetranychidae) (Faraone et al. 2018, 2020). In our study, granite dust was more repellent than Fossil Shell Flower was. We find this interesting because the use of diatomaceous earth for pest management is well documented (Subramanyam and Roesli 2000): for example, Nwaubani et al. (2014) found that Sitophilus oryzae (Coleoptera: Curculionidae) and Rhyzopertha dominica (Coleoptera: Bostrichidae) avoided wheat (Poales) treated with diatomaceous earth.

In long-term repellency laboratory trials, pine oil was the most repellent compound, and it remained consistently repellent over the 72-hour test period. Interestingly, it appears to be more repellent when used in long-term experiments than it does when used in short-term experiments. We see no clear explanation for this difference. Five products - Timorex Gold, potassium metabisulfite, basil oil, granite dust, and Ecotrol EC - decreased in repellency from 24 to 72 hours. Products may lose repellency over time due to degradation, volatilisation, or sorption. For example, Riddick et al. (2008) found that the repellent effect of terpenoids derived from catnip oil (Lamiales) and grapefruit seed (Sapindales) on multicoloured Asian lady beetle decreased significantly 24 hours after application. Tea tree oil, when applied to livestock, is repellent to adult horn flies, Haematobia irritans (Linnaeus) (Diptera: Muscidae), for up to 24 hours after application, but by 48 hours, no repellency remains (Klauck et al. 2014). Because these products decrease in repellency over time, their potential impact on wine might be reduced.

In contrast to laboratory trials, few products were significantly repellent in our field trials (Table 3). In field trials, the reduction in multicoloured Asian lady beetle numbers was statistically significant in plots treated with Biobenton, Buran, and Solfobenton. When conducting behavioural assays, effects observed in the laboratory are not necessarily observed in the field (Wallingford et al. 2017). For example, multicoloured Asian lady beetles are highly attracted to $\beta$-caryophyllene in controlled laboratory experiments (Brown et al. 2006; Verheggen et al. 2007) but not under field conditions (Nalepa et al. 2000). The future use of these products to 
Table 3. Mean ( \pm standard error) number of multicoloured Asian lady beetles (MALB) present on grape vines after application of potentially repellent compounds. Treatment effect relative to the control is displayed as per cent difference. Trials were conducted in a Riesling and a Pinot noir block in 2017. Counts were conducted 2-6 hours (Day 0) and 24-28 hours (Day 1) after spraying. Treatments that were significantly different from the control are indicated by an asterisk $\left(^{\star}\right)(\alpha=0.05)$.

\begin{tabular}{|c|c|c|c|c|c|c|}
\hline \multirow[b]{2}{*}{ Test compound } & \multicolumn{2}{|c|}{ Day 0} & \multicolumn{2}{|c|}{ Day 1} & \multicolumn{2}{|c|}{ Overall } \\
\hline & $\begin{array}{l}\text { Mean ( } \pm \text { standard error) } \\
\text { no. MALB per panel }\end{array}$ & $\begin{array}{l}\text { Reduction compared } \\
\text { to control }(\%)\end{array}$ & $\begin{array}{l}\text { Mean ( } \pm \text { standard error) } \\
\text { no. MALB per panel }\end{array}$ & $\begin{array}{l}\text { Reduction compared } \\
\text { to control }(\%)\end{array}$ & $\begin{array}{l}\text { Mean ( } \pm \text { standard error) } \\
\text { no. MALB per panel }\end{array}$ & $\begin{array}{l}\text { Reduction compared } \\
\text { to control }(\%)\end{array}$ \\
\hline Control & $24.6( \pm 4.2)$ & - & $31.5( \pm 4.9)$ & - & $27.9( \pm 4.1)$ & - \\
\hline Agral $^{\circledR} 90$ & $23.9( \pm 4.1)$ & 3 & $26.9( \pm 4.5)$ & 15 & $25.4( \pm 3.9)$ & 9 \\
\hline Biobenton $^{\circledR}$ & $15.8( \pm 3.2)$ & 36 & $18.0( \pm 3.5)$ & $43^{*}$ & $16.9( \pm 3.0)$ & $39^{*}$ \\
\hline Buran $^{\circledR}$ & $15.5( \pm 3.2)$ & 37 & $21.8( \pm 3.9)$ & 31 & $18.4( \pm 3.2)$ & $34^{*}$ \\
\hline Ecotrol $^{\circledR} \mathrm{EC}$ & $18.4( \pm 3.7)$ & 25 & $25.8( \pm 4.5)$ & 18 & $21.8( \pm 3.7)$ & 22 \\
\hline $\begin{array}{l}\text { Potassium } \\
\text { metabisulfite }\end{array}$ & $21.4( \pm 3.9)$ & 13 & $23.3( \pm 4.1)$ & 26 & $22.3( \pm 3.7)$ & 20 \\
\hline Mako & $1.6( \pm 1.0)$ & $93^{*}$ & $1.4( \pm 0.9)$ & $96^{*}$ & $1.5( \pm 0.8)$ & $95^{\star}$ \\
\hline Pine oil & $21.5( \pm 3.8)$ & 13 & $25.3( \pm 4.2)$ & 20 & $23.3( \pm 3.7)$ & 16 \\
\hline Solfobenton ${ }^{\circledR}$ & $18.8( \pm 3.7)$ & 24 & $19.9( \pm 3.9)$ & $37^{\star}$ & $19.3( \pm 3.4)$ & 31 \\
\hline Timorex Gold ${ }^{\circledR}$ & $18.8( \pm 3.5)$ & 24 & $22.7( \pm 4.0)$ & 28 & $20.6( \pm 3.4)$ & 26 \\
\hline
\end{tabular}


mitigate multicoloured Asian lady beetle in vineyards is possible, because some are already registered for use on grapes to control other pests in Canada. Although Biobenton and Solfobenton were both repellent in short-term laboratory trials, they were not repellent until Day 1 in our field trials. The slower response time of the beetles to these compounds in the field may have been due to environmental conditions, because cooler temperatures and mild winds are not ideal for multicoloured Asian lady beetle flight (Nalepa et al. 2005). Therefore, adults may have taken comparatively longer to move away from Biobenton and Solfobenton in the field.

The beetles were repelled by potassium metabisulfite at $10 \mathrm{~g} / \mathrm{L}$ in our laboratory trials, but the same rate was not repellent in the field. In contrast, Glemser et al. (2012) found that the $5 \mathrm{~g}$ potassium metabisulfite/L treatment was significantly repellent to the beetles in the field. In our study, the mean wind speed was higher (data not shown) than that during the experiments conducted by Glemser et al. (2012). It is possible that the stronger wind may have increased the dissipation rate of repellent sulfur dioxide from treated vines, relatively reducing the effectiveness of potassium metabisulfite in our study.

Mako is currently used in Ontario to control multicoloured Asian lady beetle before harvest. Mako-treated panels in our study had a mean of 1.5 beetles each. Interestingly, the majority of those beetles at both sites were dead and stuck within the cluster between grapes. Such dead beetles are a potential source of wine contamination that may have previously been unrecognised. Our observation is particularly noteworthy because dead multicoloured Asian lady beetles can adversely affect wine quality for three to six days after death (Pickering et al. 2008).

The most effective repellent in our field trails was Biobenton, which reduced the beetle's numbers by $39 \%$. Based on these results, if a winery accepted a "safe" level of 1.5 beetles per vine, Biobenton would be suitable for use if the initial beetle population did not exceed 2.4 beetles per vine. This represents a relatively low multicoloured Asian lady beetle population in Niagara vineyards, given that the mean number of beetles found per vine was 4.9 (24.6/panel; Table 3) in our study, and Glemser et al. (2012) reported 18 beetles per vine. This suggests that the use of repellents to mitigate wine taint becomes increasingly difficult with larger beetle populations. Similarly, Rodriguez-Saona and Stelinski (2009) reported that behaviour-modifying controls are most effective when pest populations are small.

There was a significant interaction between location and day, which indicates that the response of multicoloured Asian lady beetles differed in locations across days. Differences in the environment during our trials may explain this effect. The Riesling trial received $4.6 \mathrm{~mm}$ of precipitation between counting periods (i.e., after the two to six hour period), whereas the Pinot noir trial did not receive any precipitation (data not shown). It is likely that treatments were washed off in the Riesling trial, reducing their effectiveness before the second counting period. Re-application of treatments was not possible due to space limitations in the vineyard and the growers' need to harvest grapes.

Although most of the compounds tested were not significantly repellent in field trials, all provided some repellency compared to the untreated-grape controls. Therefore, some of these products may be used along with other control tactics to improve the integrated pest management of multicoloured Asian lady beetle in vineyards. To improve the effectiveness of these compounds, future studies should both test higher rates and test use of multiple compounds simultaneously. We believe that environmental factors, such as wind and temperature, influence how the beetles respond to repellent compounds, and we recommend that future studies examine these interactions.

Acknowledgements. The authors thank Sheena Morrison, Laura Finlay, Irina Perez, Dominic Pieroni, and Aleyna Burns for their technical support in the laboratory and field and also grower cooperators for providing vines for field trials. Funding for this project was kindly provided by Ontario Grape \& Wine Research Incorporated, the Canadian Agricultural Partnership, and the Canadian Grapevine Certification Network. 


\section{References}

Bahlai, C.A. and Sears, M.K. 2009. Harmonia axyridis and Aphis glycines population dynamics in Niagara peninsula area soybean fields: a case study. Journal of the Entomological Society of Ontario, 140: 27-39.

Bekele, A.J., Obeng-ofori, D., and Hassanali, A. 1996. Evaluation of Ocimum suave (Willd) as a source of repellents, toxicants and protectants in storage against three stored product insect pests. International Journal of Pest Management, 42: 139-142.

Belchim Crop Protection Canada Inc. 2019. Mako ${ }^{\text {mot }}$ Insecticide label [online]. Available from https://www.bartlett.ca [accessed 23 August 2020].

Bendre, R., Bagul, S., and Rajput, J. 2018. Carvacrol: an excellent natural pest control agent. Natural Products Chemistry \& Research, 6: 349.

Berkvens, N., Bonte, J., Berkvens, D., Deforce, K., Tirry, L., and De Clercq, P. 2008. Pollen as an alternative food for Harmonia axyridis. BioControl, 53: 201-210.

Bin, M., Ahmad, M.S., Aslam, M., and Mamat, A. 2016. Insect repellent properties of Melaleuca alternifolia. Recent Advances in Biology and Medicine, 2: 57-61.

Brown, A.E., Riddick, E.W., Aldrich, J.R., and Holmes, W.E. 2006. Identification of (-)- $\beta$-caryophyllene as a gender-specific terpene produced by the multicolored Asian lady beetle. Journal of Chemical Ecology, 32: 2489-2499.

Cook, S.M., Khan, Z., and Pickett, J. 2007. The use of push-pull strategies in integrated pest management. Annual Review Entomology, 52: 375-400.

Dethier, V.G., Browne, L.B., and Smith, C.N. 1960. The designation of chemicals in terms of the responses they elicit from insects. Journal of Economical Entomology, 53: 134-136.

Essig, E.O. 1965. A history of entomology (reprint edition). Hafner Publishing Company, New York, United States of America.

Faraone, N., Evans, R., LeBlanc, J., and Hillier, N.K. 2020. Soil and foliar application of rock dust as natural control agent for two-spotted spider mites on tomato plants. Scientific Reports, 10: 1-9.

Faraone, N., MacPherson, S., and Hillier, N. 2018. Evaluation of repellent and insecticidal properties of a novel granite dust product in crop protection. Journal of Pest Science, 91: $1345-1352$.

Galvan, T.L., Kells, S., and Hutchison, W.D. 2008a. Determination of 3-alkyl-2-methoxypyrazines in lady beetle-infested wine by solid-phase microextraction headspace sampling. American Journal of Enology and Viticulture, 56: 1065-1071.

Galvan, T.L., Koch, R.L., and Hutchison, W.D. 2008b. Impact of fruit feeding on overwintering survival of the multicolored Asian lady beetle, and the ability of this insect and paper wasps to injure wine grape berries. Entomologia Experimentalis et Applicata, 128: 429-436.

Glemser, E.J., Dowling, L., Inglis, D., Pickering, G.J., McFadden-Smith, W., Sears, M.K., and Hallett, R.H. 2012. A novel method for controlling multicolored Asian lady beetle (Coleoptera: Coccinellidae) in vineyards. Environmental Entomology, 41: 1169-1176.

Gordon, R.D. 1985. The Coccinellidae (Coleoptera) of America north of Mexico. Journal of the New York Entomological Society, 93: 1-912.

Health Canada. 2002. Regulatory Directive: The PMRA initiative for reduced-risk pesticides (DIR2002-02). Pest Management Regulatory Agency, Health Canada, Ottawa, Ontario, Canada. Available from https:/www.canada.ca/en/health-canada/services/consumer-productsafety/reports-publications/pesticides-pest-management/policies-guidelines/regulatory-directive/ 2002/initiative-reduced-risk-pesticides-dir2002-02.html [accessed 8 November 2020].

Hodek, I., Iperti, G., and Hodkova, M. 1993. Long-distance flights in Coccinellidae (Coleoptera). European Journal of Entomology, 90: 403-414.

Isman, M. 2000. Plant essential oils for pest and disease management. Crop Protection, 19: 603-608. 
James, D.G. 2005. Further field evaluation of synthetic herbivore-induced plant volatiles as attractants for beneficial insects. Journal of Chemical Ecology, 31: 481-495.

James, D.G. and Price, T.S. 2004. Field-testing of methyl salicylate for recruitment and retention of beneficial insects in grapes and hops. Journal of Chemical Ecology, 30: 1613-1629.

Ker, K.W. and Pickering, G.J. 2005. Biology and control of the novel grapevine pest - the multicoloured Asian ladybeetle - Harmonia axyridis. In Crops: growth, quality and biotechnology. Edited by R. Dris. WFL Publisher, Helsinki, Finland. Pp. 991-997.

Klauck, V., Pazinato, R., Stefani, L.M., Santos, R.C., Vaucher, R.A., Baldissera, M.D., et al. 2014. Insecticidal and repellent effects of tea tree and andiroba oils on flies associated with livestock. Medical and Veterinary Entomology, 28: 33-39.

Koch, R.L. 2003. The multicolored Asian lady beetle, Harmonia axyridis: a review of its biology, uses in biological control, and non-target impacts. Journal of Insect Science, 3: 1-16.

Maier, R.M. and Williamson, R.C. 2016. Evaluation of kaolin clay as an alternative management tactic for Japanese beetle feeding damage in grape vineyards. Journal of Horticulture, 3: 1-6.

Nalepa, C.A., Kennedy, G.G., and Brownie, C. 2005. Role of visual contrast in the alighting behavior of Harmonia axyridis (Coleoptera: Coccinellidae) at overwintering sites. Environmental Entomology, 34: 425-431.

Nalepa, C.A., Kidd, K.A., and Hopkins, D.I. 2000. The multicolored Asian lady beetle (Coleoptera: Coccinellidae): orientation of aggregation sites. Journal of Entomological Science, 35: 150-157.

Nerio, L.S., Olivero-Verbel, J., and Stashenko, E. 2010. Repellent activity of essential oils: a review. Bioresource Technology, 101: 372-378.

Nwaubani, S.I., Opit, G.P., Otitodun, G.O., and Adesida, M.A. 2014. Efficacy of two Nigeriaderived diatomaceous earths against Sitophilus oryzae (Coleoptera: Curculionidae) and Rhyzopertha dominica (Coleoptera: Bostrichidae) on wheat. Journal of Stored Products Research, 59: 9-16.

Park, J., Jeon, Y., Lee, C., Chung, N. and Lee, H. 2017. Insecticidal toxicities of carvacrol and thymol derived from Thymus vulgaris Lin. against Pochazia shantungensis Chou \& Lu., newly recorded pest. Scientific Reports, 7: 40902.

Pickering, G.J., Ker, K., and Soleas, G.J. 2007. Determination of the critical stages of processing and tolerance limits for Harmonia axyridis for 'ladybug taint' in wine. Vitis, 46: 85-90.

Pickering, G.J., Lin, Y., and Ker, K. 2005. Origin and remediation of Asian lady beetle (Harmonia axyridis) taint in wine. In Crops: growth, quality and biotechnology. Edited by R. Dris. WFL Publisher, Helsinki, Finland. Pp. 785-794.

Pickering, G.J., Lin, J., Riesen, R., Reynolds, A., Brindle, I., and Soleas, G. 2004. Influence of Harmonia axyridis on the sensory properties of white and red wine. American Journal of Enology and Viticulture, 55: 153-159.

Pickering, G.J., Spink, M., Kotseridis, Y., Brindle, I.D., Sears, M., and Inglis, D. 2008. The influence of Harmonia axyridis morbidity on 2-isopropyl-3-methoxypyrazine in Cabernet sauvignon wine. Vitis, 47: 227-230.

Riddick, E.W., Aldrich, J.R., De Milo, A., and Davis, J.C. 2000. Potential for modifying the behavior of the multicolored Asian lady beetle (Coleoptera: Coccinellidae) with plant-derived natural products. Annals of the Entomological Society of America, 93: 1314-1321.

Riddick, E.W., Brown, A.E., and Chauhan, K.R. 2008. Harmonia axyridis adults avoid catnip and grapefruit-derived terpenoids in laboratory bioassays. Bulletin of Insectology, 61: 81-90.

Rodriguez-Saona, C. and Stelinski, L.L. 2009. Behavior-modifying strategies in IPM. In Integrated pest management: innovation-development process. Edited by R. Peshin and A.K. Dhawan. Springer, New York, New York, United States of America. Pp. 261-311.

Seko, T., Yamashita, K., and Miura, K. 2008. Residence period of a flightless strain of the ladybird beetle Harmonia axyridis Pallas (Coleoptera: Coccinellidae) in open fields. Biological Control, 47: 194-198. 
Subramanyam, B. and Roesli, R. 2000. Inert dusts. In Alternatives to pesticides in stored-product IPM. Edited by B. Subramanyam and D.W. Hagstrum. Springer, Boston, Massachusetts, United States of America. Pp. 321-380.

Tourniaire, R., Ferran, A., Gambier, J., Giuge, L., and Bouffault, F. 1999. Locomotor behavior of flightless Harmonia axyridis Pallas (Col., Coccinellidae). Journal of Insect Behavior, 12: $545-558$.

United States Government Publishing Office. 1996. Food Quality Protection Act of 1996 [online]. United States Government, Washington, D.C., United States of America. Available from https:// www.govinfo.gov/content/pkg/PLAW-104publ170/pdf/PLAW-104publ170.pdf [accessed July $21,2020]$.

Ujváry, I. 2010. Pest control agents from natural products. In Hayes' handbook of pesticide toxicology (3rd edition). Edited by R. Krieger. Academic Press, London, United Kingdom. Pp. 119-229.

Verheggen, F.J., Fagel, Q., Heuskin, S., Lognay, G., Francis, F., and Haubruge, E. 2007. Electrophysiological and behavioral responses of the multicolored Asian lady beetle, Harmonia axyridis Pallas, to sesquiterpene semiochemicals. Journal of Chemical Ecology, 33: $2148-2155$.

Wallingford, A.K., Cha, D.H., Linn, C.E., Wolfin, M.S., and Loeb, G.M. 2017. Robust manipulations of pest insect behavior using repellents and practical application for integrated pest management. Environmental Entomology, 46: 1041-1050.

Werle, C.T., Addesso, K.M., Sampson, B.J., Oliver, J.B., and Adamczyk, J.J. 2017. Integrating kaolin clay for ambrosia beetle management in ornamental crops of eastern redbud. HortScience, 52: 94-98.

Cite this article: Glemser, E., McFadden-Smith, W., and Parent, J.-P. 2021. Evaluation of compounds for repellency of the multicoloured Asian lady beetle (Coleoptera: Coccinellidae) in vineyards. The Canadian Entomologist, 153: 470-481. https:// doi.org/10.4039/tce.2020.82. 